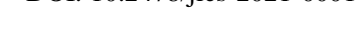

\title{
PRACTICAL ISSUES REGARDING INTERNATIONAL UNDERPPINNINGS OF TAX LEGISLATION UNDER THE AUSPICES OF LAW NO. 296/2020
}

\author{
Florin Cornel Dumiter* \\ "Vasile Goldiş, Western University of Arad, Romania, E-mail: fdumiter@yahoo.com \\ Ștefania Amalia Jimon \\ ’Vasile Goldiş" Western University of Arad, Romania, E-mail: jimonstefania@yahoo.com
}

(Received: January 2021; Accepted: March 2021; Published: May 2021)

\begin{abstract}
In this article, it will be analyzed, from the perspective of doctrine and jurisprudence, the implications of some international aspects of tax legislation, under the auspices of the latest changes in the field of taxation made by Romania. For this purpose, it will be analyzed the implications of the new fiscal provisions regarding the international aspects from the perspective of Law no. 296/2020. In this sense, it will be focused upon certain issues such as international double taxation, transfer prices, affiliated businesses and corporate tax. Also, the case presented in the jurisprudence section enriched in the second part of the article comes to support the framework of the future application of the new provisions regarding certain fiscal aspects with elements of foreignness in Romania. The results of the research subsumed in this article highlight the fact that the tax legislation in Romania has had a significant improvement, especially in terms of international aspects of financial and tax law. In conclusion, both the analysis of the evolution of tax legislation and the case law presented show that there are significant improvements at a national level, both in terms of the quality of the enactment of a tax law and the way in which the provisions of the law are implemented in practice.
\end{abstract}

Keywords: Tax Code; taxation, tax law; international taxation; jurisdiction; resident.

\section{Introduction and literature review}

The international aspects of taxation manifested both from a legal point of view and an economic point of view, are particularly important. Developments in European and international tax law in recent years in terms of "refinement", comprehensiveness, complexity and an integrated approach are obvious. Due to the multi-inter-transdisciplinary aspects of the elements regarding financial and fiscal

\footnotetext{
${ }^{*}$ Corresponding author: Florin Cornel Dumiter.E-mail: fdumiter@yahoo.com
} reproduction in any medium, provided the original author and source are credited. 
Dumiter, F.C., Jimon, Ș.A., (2021)

Practical Issues Regarding International Underppinnings of Tax Legislation Under the Auspices of Law No. $296 / 2020$

law, tax authorities of many emerging and developed countries have built tax strategies to meet the difficult problems manifested at a national and international level.

The objective of this article is the analysis of the legislative implications established by Law no. 296/2020. This law redefines the national tax framework and reaffirms international prerogatives regarding aspects of tax law with elements of foreignness. A second objective aimed at the historical analysis of the legislative evolution in fiscal matters of the legislation, this being a quid pro quo in establishing the concrete way of evolution of the fiscal legislation in Romania.

The purpose of this article was to analyze the tax implications established at the end of 2020 from the perspective of the Tax Code in Romania, but also the analysis of an interesting case from national jurisprudence, given the establishment of income tax based on the value of management and research services on the intra-Community market of Poland, Hungary and the Czech Republic. In this respect, this case has been chosen from the national jurisprudence because it constitutes an important basis for the analysis of the jurisprudential mechanism of application in practice of the existing provisions and connection with the new fiscal regulations in the field.

Van der Vijver (2015) conducts a comparative study on European legal principles of double taxation versus double non-taxation, the author concluding that there must be a clear delimitation between the two elements mentioned above supported by international organizations and national parliaments. Smit (2016) analyzes the status quo of non-juridical double taxation presenting certain jurisprudential aspects manifested especially at a European and international level, the author suggesting that the various problems that may arise in avoiding double legal taxation may arise due to issues related to international tax planning.

Practical issues regarding double taxation avoidance conventions from a jurisprudential perspective were addressed by Dumiter et al. (2017). In this study, the authors started from the institutional framework of national and international double taxation conventions. In the first part of the research, the authors highlighted the economic and legal framework of double taxation conventions, while the last part of the study was the analysis of a case study from national jurisprudence, regarding the income obtained by non-residents in Romania under the auspices of the convention, concluded between Romania and Great Britain (the United Kingdom and Northern Ireland) by Decree no. 26/1976. The authors conclude that the application of the framework of tax conventions needs to be improved in national case law.

Dumiter \& Jimon (2018) emphasize that horizontal and vertical equity regarding the taxation of non-residents in Romania applied to economic entities must have a solid basis for strengthening technical, administrative and economic capacities, as well as

2 Journal of Legal Studies Volume 27 Issue 41/2021

$\checkmark$ sciendo ISSN 2457-9017; Online ISSN 2392-7054.

Web: publicatii.uvvg.ro/index.php/jls. Pages $1-16$ 
Dumiter, F.C., Jimon, Ș.A., (2021)

Practical Issues Regarding International Underppinnings of Tax Legislation Under the Auspices of Law No. 296/2020

sustainable tax practices by tax authorities. The case presented from the national jurisprudence highlights the fact that the taxation of non-resident entities in Romania must be improved by consolidating the legislative framework, but also by improving the administrative capacity of the national tax authorities.

Improving the national framework for the interpretation and application of international double taxation conventions is based on the OECD Model Convention and the UN Model Convention. According to Dumiter et al. (2019), the increasingly complex tax causes regarding the taxation of income and capital must lead, ceteris paribus, to the consolidation of the multilateral convention to avoid double taxation in order to mitigate the effects of treaty shopping practices. Moreover, the complex issues imposed by cross-border transfer pricing are the main agenda of all actors in the tax field, both at a European and international level. Dumiter \& Jimon (2020) highlight the main economic and legal issues of transfer pricing and analyze how they can be applied in a relevant case in national case law.

Dumiter (2020) analyzes the problem of avoiding international double taxation through a double perspective: theoretical aspects and practical agenda. This study highlights the multiple tax problems faced by policymakers, tax authorities, economic entities, multinational companies and individuals.

At a European level, there are some interesting studies on this issue. One of these is that of de Groot (2015) which addresses the issue of inconsistency between the application of the tax credit and the deduction method, requiring a significant improvement in the provisions of the Parent-Subsidiary Directive. Khan Niazi \& Krever (2015) also suggest the need for the Member States of the European Union to adopt rules on tax harmonization in the field of direct taxation of income and capital.

The structure of this article is as follows: the first section contains introductory notions regarding several aspects of doctrinal importance regarding international taxation manifested in the judicial literature, their implications, and limitations; the second section presents the historical evolution trend of the Romanian's Tax Code and Tax Procedure Code with their specific timeline appliance aspects; section 3 highlights the major important practical shifts regarding international aspects of tax issues revealed by up-to-date Romania's legislation; the fourth section analyzes some interesting judicial and economic insights regarding practical tax issues enriched in the Romanian jurisprudence; the last section concludes with the final considerations and remarks regarding the debated topic and underlines some future research paths.

2. Romanian's Tax Code and Tax Procedure Code - historical legislation review In this section, it will be presented and analyzed the developments of the Tax Code after 1990 to observe how the tax legislation has improved and how the legislator 
Dumiter, F.C., Jimon, Ș.A., (2021)

Practical Issues Regarding International Underppinnings of Tax Legislation Under the Auspices of Law No. 296/2020

has managed to clarify certain aspects of national tax law. We also propose an analysis of the extent to which the enactment of aspects related to international taxation has been successfully implemented, but also of the incidence of foreign elements within the legislation of financial and fiscal law at a national level.

The implications of the fiscal legislation of Law no. 571/2003 in conjunction with GD 44/2004 on the Fiscal Code regarding the income tax obtained by non-residents in Romania, as well as the representations of foreign economic entities established in Romania was included in Title V.

Chapter 1 "Income tax obtained in Romania by non-residents" establishes different categories of taxable income obtained in Romania, as well as the main types of income that are not subject to taxation. Art. 118 aims the harmonizing the provisions of the Tax Code with the double taxation avoidance conventions but also with other provisions of the European Union legislation, among which we mention: the concrete way of setting the tax rate, the obligation to obtain the tax residence certificate from the competent authority, and the manner in which additional withholding tax may be refunded exclusively on the basis of the request of the beneficiary.

Chapter 2 "Tax on representations" engrams the method of establishing the tax related to representations which for a tax year is the equivalent of 4,000 euros established at the exchange rate established by the National Bank of Romania. Also, the provisions of art. 124 stipulates the obligation to pay the tax in two installments: until the dates of June 25, respectively December 25, inclusive.

Chapter 3 deals with the manner of taxation of the incomes obtained in Romania by natural persons resident in the Member States, as well as the modalities of application of the exchange of information regarding these aspects. Article 124 alin. (1) and alin. (2) establish the framework for defining the beneficial owner, as well as his identity and place of residence. Regarding the avoidance of double taxation, according to art. 124 para. (14) in case there are situations where double taxation is registered, the Romanian state reimburses the additional tax to the beneficial owner. Chapter 4 "Royalties and interest on associated enterprises", through art. 124 alin. (20) defines the terminology of enterprise, associated enterprise and permanent establishment through the terminology specific to different states, and through art. 124 alin. (22) fraud and abuse constitute one of the acts of fraud, tax evasion, or any type of abuse.

4 Ssciendo

Journal of Legal Studies Volume 27 Issue 41/2021

ISSN 2457-9017; Online ISSN 2392-7054

Web: publicatii.uvvg.ro/index.php/jls. Pages $1-16$ 
Dumiter, F.C., Jimon, Ș.A., (2021)

"Vasile Goldiş" Western University of Arad

Practical Issues Regarding International Underppinnings of Tax Legislation Under the Auspices of Law No. 296/2020

3. New practical tax issues revealed by the Romanian's modified Tax Code enriched by the Law No. 296/2020 regarding the modification and completion of Law no. 227/2015

The most important amendments brought by law no. 296/2020 for the modification and completion of Law no. 227/2015 on Tax Code in the fields of taxation and international tax law are analyzed, in this section from the perspective of double taxation, transfer pricing and consolidation of corporate tax.

\subsection{Double Taxation Issues}

An important aspect is represented by the place of effective management which, according to the provisions of art. 18 para. (a) and (b) is the place where the foreign legal entity carries out different types of operations with real and substantial economic purpose in such a way that: (i) the executive directors undertake executive measures regarding the management of the company in Romania; and (ii) is established the residence of at least $50 \%$ of the members of the board of directors or the executive directors of the foreign company.

The terminology of a legal entity affiliated with another legal entity, according to art. 26 para. (d) means, sui generis, where it holds at least $25 \%$ of the value of the voting rights or the number of shares, either in the first legal person or in the second. According to art. 37 para. (b) the term resident is defined, from the point of view of a Romanian legal person, as that entity which has in Romania the place of exercising effective management, it is established on the basis of European legislation, as well as any resident natural person.

According to the provisions of art. 8 alin. (1) of the double taxation avoidance agreement concluded by Romania with the respective state will represent the foundation for establishing the place of effective management of a foreign legal entity. The establishment of the residence is made on the basis of several documents, according to alin. (2), as well as based on the questionnaire enclosed in art. 230 para. (8).

It is interesting to note a unitary application that includes the same conditions and situations, both in terms of foreign legal entities resident in Romania, legal entities located in Romania, and Romanian legal entities, based on the provisions of art. 23, 24, 32, 34, 38, 39 and 43.

According to art. 35 para. (6): the tax credit granted by the tax authorities in respect of taxes paid during a fiscal year may not exceed the amount of corporate tax, determined by applying the tax rate to the taxable profit obtained in the foreign state. 
Dumiter, F.C., Jimon, Ș.A., (2021)

Practical Issues Regarding International Underppinnings of Tax Legislation Under the Auspices of Law No. 296/2020

\subsection{Transfer prices and corporate tax}

According to art. 42 alin. (1) the term of the tax group in the field of corporate tax must meet at least two members of the following entities:

i. a legal entity with its registered office in Romania and one or more companies in which it holds at least $75 \%$ of the value of their participation titles/voting rights;

ii. a natural person holding at least $75 \%$ of the value of the participation titles/ voting rights in at least two Romanian legal entities;

iii. at least two Romanian legal entities holding $75 \%$ of the value of the participation titles/voting rights, either directly or indirectly;

iv. at least one Romanian legal entity holding $75 \%$ of the value of the participation titles/voting rights, either directly or indirectly;

Regarding the entry and/or exit from a fiscal group, according to the provisions of art. 42 alin. (4): the entry is made (with the fulfillment of the conditions) starting from the next fiscal year; the exit implies the non-application of the taxation system starting with the quarter following the unfulfillment of the conditions; the reorganization is carried out during the fiscal year.

The elements that will be taken into account when determining the quarterly/annual profit tax due, according to the provisions of art. 42 alin. (5) are tax credit, profit tax reductions and exemptions, expenses regarding patronage and/or sponsorship, private scholarships, the cost of purchasing electronic fiscal cash registers. It is interesting to note that all these amounts will be deducted from the profit tax due by the tax group.

Based on the provisions of art. 42 alin. (6) in the field of transfer prices, each member of a tax group will have the obligation to prepare the documentation on transfer prices, both in respect of affiliated entities outside the group and all transactions with members of the tax group.

Regarding the anti-abuse rules, according to art. 42 alin. (11) its provisions do not apply in cases where tax fraud and evasion may materialize, by means of the establishment of the profit tax based on the fiscal consolidation system.

\section{The case: A. South Central Europe S.A. versus DRFP Galați - AJFP Buzău regarding additional profit tax derived from management and marketing research services conferred by companies: A. Poland, A. Hungary, and A. the Czech Republic}

In this section we will present and analyze Decision no. 1716/2020 of March 25, 2020, of the High Court of Cassation and Justice of Romania, Administrative and Fiscal Litigation Section regarding the settlement of the appeal filed by plaintiff A. South Central Europe S.A. against the Civil Sentence no. 131 of 29.06 .2018 and the

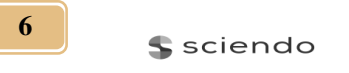

6 Ssciendo
Journal of Legal Studies Volume 27 Issue 41/2021 ISSN 2457-9017; Online ISSN 2392-7054 Web: publicatii.uvvg.ro/index.php/jls. Pages $1-16$ 
Dumiter, F.C., Jimon, Ș.A., (2021)

"Vasile Goldiş" Western University of Arad

Practical Issues Regarding International Underppinnings of Tax Legislation Under the Auspices of Law No. 296/2020

Sentence no. 177 of 17.10.2017 pronounced by the Court of Appeal of Ploieşti, civil section II, of administrative and fiscal contentious regarding the amount of $1,453,803.04$ lei, representing profit tax established additionally by the Tax Decision no. $x / 26.09 .2016$ and the Tax Inspection Report no. $x / 26.09 .2016$ issued by the National Agency for Fiscal Administration - General Regional Directorate of Public Finances Galați - Administration of Public Finances, Buzău County (High Court of Cassation and Justice of Romania, Administrative and Fiscal Litigation Section, Decision no. 1716, pronounced in public session on March 25, 2020).

\section{Circumstances of the case}

Plaintiff A. South Central Europe S.A. in contradiction with the defendants, the National Agency for Fiscal Administration (ANAF) - General Regional Directorate of Public Finances Galați - Administration of Public Finances, Buzău County and General Directorate for Administration of Large Taxpayers (DGAMC) requested the Court of Appeal of Ploieşti, section II civil, administrative and fiscal contentious the cancelation of the following administrative-fiscal acts:

- The decision to settle the contestation no. 5676/08.12.2016, rejecting as unfounded the plaintiff's appeal regarding the request for recognition of the deductibility of expenses with purchased services, in the total amount of 9,086,269 lei, and as a result, the decrease of the profit tax declared and paid by the company, but undue, in the amount of 1,453,803.04 lei;

- Taxation decision no. $\mathrm{x} / 26.09 .2016$ and the Tax Inspection Report no. $\mathrm{x} / 26.09 .2016$ regarding the non-recognition by the fiscal inspection bodies of the deductibility of the expenses with the purchased services, in a total amount of 9,086,269 lei between 2013 - 2014 and the first quarter of 2015 and the denial to establish in minus the amount of $1,453,803.04$ lei, representing profit tax declared and paid by the company, but not due;

- Decision no. 60/26.05.2017 issued by the defendant DGAMC, only with respect to point 2 of this decision, by which it found the incompetence to resolve the tax contestation regarding the request for recognition of the deductibility of expenses with the services purchased by the plaintiff;

Moreover, the plaintiff requests the obligation of the defendant DGAMC to reimburse the amounts additionally paid and not owed as income tax and the obligation of the defendants to pay the costs occasioned by the settlement of the present case, pursuant to art. 453 of Code of Civil Procedure.

\section{The solution of the court of the first instance}

The action brought by the plaintiff A. South Central Europe SA, in contradiction with the defendants National Agency for Fiscal Administration - General Regional 
Dumiter, F.C., Jimon, Ș.A., (2021)

Practical Issues Regarding International Underppinnings of Tax Legislation Under the Auspices of Law No. 296/2020

Directorate of Public Finances Galați - Administration of Public Finances, Buzău County and the General Directorate for Administration of Large Taxpayers regarding the annulment of administrative acts issued by the defendants was admitted in part by the Court of Appeal Ploieşti, civil section II, of administrative contentious.

By the civil Sentence no. 131 of 29.06.2018, the Court of Appeal Ploieşti decided to cancel the Decision for solving the contestation no. 5676/8.12.2016, partially annulled the Tax Decision no. $\mathrm{x} / 26.09 .2016$ and the Tax Inspection Report no. $\mathrm{x} / 26.09 .2016$ and rejected the request for annulment of point 2 of Decision no. 60/26.05.2017 issued by the defendant DGAMC. It also obliged the defendant DGRFP Galaţi - A.J.F.P. Buzău to pay the plaintiff the amount of 3,820 lei, representing expert fee and stamp duty, as well as the amount of 10,000 lei, as a lawyer's fee, reduced by the court, according to art. 451 of Code of Civil Procedure. In substantiating the decision, the Court notes that through the Tax Inspection Report no. $x$ of 26.09.2016 and the Tax Decision no. $x$ of 26.09.2016, issued on its basis, it was noted that the company would not have the right to deduct VAT in the amount of RON 2,180,705, related to "management and marketing research" services, amounting to 9,086,269 lei, provided by A. Poland, A. Hungary, and A. the Czech Republic, between 2013-2015.

The company considered its initiative and included in the taxable profit of the tax years 2013, 2014 and for the first half of 2015, the value of management and marketing research services on the intra-Community market, respectively in Poland, Hungary, Czech Republic, for the amount total of 9,086,269.13 lei, as non-taxdeductible expenses. In this way the calculation of the profit tax was influenced:

- for 2013, the non-deductible tax expense, in the amount of 4,068,611.50 lei, included in the taxable profit;

- for 2014, the non-deductible tax expense, in the amount of 4,748,586.63 lei, included in the taxable profit;

- for the first semester of 2015, the non-tax-deductible expense in the amount of 269,071 lei.

For the total amount of 9,086,269.13 lei, representing management and marketing research services on the intra-community market in Poland, Hungary, the Czech Republic, considered non-tax-deductible expenses by the company, was deducted from the VAT returns for that period by applying the tax reverse, resulting in a deductible VAT in the amount of 2,180,704.59 lei (9,086,269.13 lei x 24\%).

By Decision no. 5676/8.12.2016, D.G.R.F.P. Galaţi - A.J.F.P. Buzău rejected the plaintiff's complaint as unfounded, as it considered that insufficient supporting documents had been submitted.

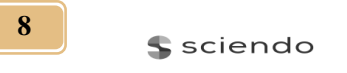

$$
S \text { sciendo }
$$

Journal of Legal Studies Volume 27 Issue 41/2021 ISSN 2457-9017; Online ISSN 2392-7054 Web: publicatii.uvvg.ro/index.php/jls. Pages $1-16$ 
Dumiter, F.C., Jimon, Ș.A., (2021)

"Vasile Goldiş" Western University of Arad

Practical Issues Regarding International Underppinnings of Tax Legislation Under the Auspices of Law No. $296 / 2020$

The plaintiff company fulfilled the conditions for the tax authority to consider deductible in the calculation of the profit tax the expenses incurred for the acquisition of the services provided by the affiliated companies. Specifically, the plaintiff company proved the actual provision of the services for the benefit of USCE through the supporting documents submitted to the tax authority and submitted to the case file. The expenses incurred with the services provided were necessary for the activity of the company and led to the obtaining of taxable income. The services in question were provided on the basis of the Services Contract CEE A. no. 18/1.07.2013.

Court of Appeal Ploieşti, civil section II, of administrative and fiscal contentious, by the civil sentence no. 177 of 17.10 .2017 , admitted the exception of inadmissibility of the request invoked by DGAMC and, consequently, rejected the request to complete the operative part of the civil sentence no.131/29.06.2018, as inadmissible.

\section{The appeal exercised}

Appellant A. South Central Europe S.A. declared an appeal against Sentence no. $131 / 29.06 .2018$ by which it requested the partial annulment of it, in the sense of admitting point 4 of the introductory court action and obliging the defendants to pay the court costs, as well as against the Sentence no. 177/17.10.2018 by which requested its cassation and, following the retrial, the admission of the request to complete the operative part of the sentence no. 131/29.06.2018 with the mention of obliging the defendants to establish in minus the amounts representing profit tax declared and paid by the company, in the amount of 1,453,803.04 lei, as requested by the lawsuit.

The appellants, the General Regional Directorate of Public Finances Galaţi, through the Administration of Public Finances, Buzău County and the General Directorate of Administration of Large Taxpayers, declared an appeal against the Sentence no. $131 / 29.06 .2018$ by which it requested its cassation and the rejection of the plaintiff's action, as unfounded.

\section{Criticism of the appellant - plaintiff A. South Central Europe S.A}

In the motivation of the appeal against sentence no. 131/29.06.2018, the appellant plaintiff A. South Central Europe S.A. claims that this was based on the incorrect application of the norms of material law, respectively of art. 1 alin. (1) of the Law on administrative litigation no. 554/2004, republished, with subsequent amendments and completions, showing that the administrative contentious courts are competent to order the reparation of the damages suffered by the injured persons, as a result of the issuance of the contested administrative acts and to restore the violated right and remove the negative consequences of the illegal act issued in public power. 
Dumiter, F.C., Jimon, Ș.A., (2021)

Practical Issues Regarding International Underppinnings of Tax Legislation Under the Auspices of Law No. 296/2020

Appellant - plaintiff A. South Central Europe S.A. motivates the action against Sentence no. 177/17.10.2018 indicating that the court failed to rule on the request to establish the reduction of corporate income tax in the amount of 1,453,803.04 lei, an omission that could lead to the possibility that the company may not enforce the sentence, in the conditions in which the fiscal body could consider that the administrative-fiscal acts were annulled, without being obliged to establish in minus the contested amounts.

Criticisms brought by the appellant - defendant Regional General Directorate of Public Finances Galați, through the Administration of Public Finances, Buzău County

In the motivation of the appeal against the civil sentence no. 131/29.06.2018, the appellant-defendant Regional General Directorate of Public Finance Galați, through the Administration of Public Finances, Buzău County claims that the first instance court did not take into account the fact that the deductibility of expenses with management services, consultancy, assistance, or other services is also determined by the availability of supporting documents that must certify the actual performance and benefit of the company. Since at the time of finalizing the calculation of the fiscal result for 2013, 2014, and the first semester of 2015, at the level of the company's financial department there were not enough supporting documents, the tax inspectors correctly considered the expenses with these services as nondeductible.

Criticisms brought by the appellant - defendant General Directorate for Administration of Large Taxpayers

The appellant - defendant, the General Directorate for the Administration of Large Taxpayers, motivated the request for the annulment of the Sentence no. 131/29.06.2018 pronounced by the Court of Appeal Ploieşti showing that the first instance did not rule on the exception of the lack of its passive procedural capacity, invoked in the content of the objection filed in the case file.

The defenses in the cause

Appellant - plaintiff A. South Central Europe S.A. filed an objection to the appeal filed by the defendants National Agency for Fiscal Administration - General Regional Directorate of Public Finance Galați - Administration of Public Finance, Buzău County and General Directorate for Administration of Large Taxpayers invoking the exception of nullity of appeals made by them. Regarding the appeal promoted by the General Regional Directorate of Public Finances Galaţi, through the Administration of Public Finances, Buzău County, the appellant claims that it

10 Journal of Legal Studies Volume 27 Issue 41/2021

$\checkmark$ sciendo ISSN 2457-9017; Online ISSN 2392-7054.

Web: publicatii.uvvg.ro/index.php/jls. Pages $1-16$ 
Dumiter, F.C., Jimon, Ș.A., (2021)

"Vasile Goldiş" Western University of Arad

Practical Issues Regarding International Underppinnings of Tax Legislation Under the Auspices of Law No. $296 / 2020$

was not motivated in fact and in law, and the ground of appeal on the provisions of art. 488 alin. (1) para. 8 of Code of Civil Procedure is made only formally, and as regards the appeal filed by the General Directorate for the Administration of Large Taxpayers, it is unfounded given that the court of first instance ruled on the exception of the lack of its passive procedural capacity by concluding a hearing in 17.10.2017, pronounced in the first procedural cycle. The appellant also states that the judgment under appeal is lawful and well-founded, the first instance court correctly retaining the deductibility of the expenses incurred by the company with the acquisition of assistance and management services.

The appellant, the General Directorate for the Administration of Large Taxpayers, objected to the appeals declared by the plaintiff by which it requested their rejection as unfounded.

Considerations of the High Court of Cassation and Justice of Romania regarding the actions of the parties

Considerations of the Court of Appeal concerning the appeal of the appellant plaintiff A. South Central Europe S.A.

The High Court of Cassation and Justice considers unfounded the appellant plaintiff's criticism regarding the fact that the first instance did not take into account the provisions of art. 1 alin. (1) of the Law on administrative litigation no. 554/2004, republished, with the subsequent amendments and completions, which enshrines an administrative contentious of subjective type, of full jurisdiction, in which it can be ordered the reparation of the damage suffered by the injured person, as a result of the issuance of administrative acts whose cancellation is required. The High Court considers that the legal text relied on is not applicable.

Also, as the first instance held, the claim having as object the obligation of the defendant DGAMC to reimburse the amounts paid extra and undue as a result of recognizing the deductibility of expenses with services received from affiliated companies, in the total amount of 9,086,269 lei when calculating the tax result for the fiscal years 2013, 2014 and the first quarter of 2015 is inadmissible. The High Court states that the special legislation provides that the taxpayer may request the refund of amounts paid in addition and undue by making a request to the tax authority which has jurisdiction of budget receivables management.

The appeal brought by the appellant- plaintiff A. South Central Europe S.A. against the civil sentence no. 177/17.10.2018, the High Court of Cassation and Justice finds that the court of first instance ruled only on the annulment of the Decision resolving the contestation and the Tax Decision in question, but failed to rule on the obligation of the defendants in setting the amounts representing the disputed profit tax, although 
Dumiter, F.C., Jimon, Ș.A., (2021)

Practical Issues Regarding International Underppinnings of Tax Legislation Under the Auspices of Law No. 296/2020

the company expressly requested this in the first head of claim of the introductory action.

According to art. 444 alin. (1) of Code of Civil Procedure, if by the given decision the court failed to rule on a main or ancillary request or a related or incidental request, the completion of the decision may be requested within the same term in which an appeal may be declared, and in the case of decisions given in extraordinary appeals or a merits after the cassation with detention, within 15 days from the pronouncement; in case of final decisions pronounced on appeal or recourse, their completion may be requested within 15 days from the communication.

Contrary to those mentioned by the first instance, the request to complete the operative part of sentence no. 131/29.06.2018 meets all the conditions imposed by the previously legal text, which is fully admissible, given that it was formulated by the company within the legal deadline for declaring the appeal against the sentence in question, and the court failed to rule on this issue.

Consequently, the High Court considers that the ground of cassation provided by art. 488 alin. (1) para. 8 of Code of Civil Procedure is well-founded.

The considerations of the appellate court regarding the appeal of the appellantdefendant National Agency for Fiscal Administration - General Regional Directorate of Public Finances Galaţi - Administration of Public Finances, Buzău County

Analyzing the content of the appeal memorandum promoted by the General Regional Directorate of Public Finances Galaţi, through the Administration of Public Finances, Buzău County, the High Court finds that it faithfully reproduces the content of the objection filed by the party in the first procedural cycle. Therefore, the appellant did not formulate criticisms of illegality regarding the contested sentence that could be circumscribed to the grounds for cassation provided in art. 488 of Code of Civil Procedure, but only summarized the presentation of the factual situation, without making any reference to the motivation of the court in the contested court decision. Therefore, the simple formal indication of the classification of the appeal in the reason regulated by the provisions of art. 488 alin. (1) para. 8 of Code of Civil Procedure is not sufficient in order to be considered fulfilled the condition of motivating the promoted appeals, circumstance against which, in relation to the provisions of art. 489 alin. (2) of the Code of Civil Procedure, the appeal is null.

Considerations of the appellate court regarding the appeal of the appellant defendant General Directorate for Administration of Large Taxpayers

The High Court considers that the appellant's criticism is unfounded, given that, as it results from the content of the conclusion of the hearing from the trial date of

12 Journal of Legal Studies Volume 27 Issue 41/2021

$\checkmark$ sciendo ISSN 2457-9017; Online ISSN 2392-7054.

Web: publicatii.uvvg.ro/index.php/jls. Pages $1-16$ 
Dumiter, F.C., Jimon, Ș.A., (2021)

"Vasile Goldiş" Western University of Arad

Practical Issues Regarding International Underppinnings of Tax Legislation Under the Auspices of Law No. $296 / 2020$

17.10.2017, the judge of the case raised in the discussion of the parties the exceptions invoked by the defendants and rejected the exception of the lack of passive procedural capacity of the General Directorate for Administration of Large Taxpayers, "since in the reply to the response, the plaintiff expressly indicated the heads of claim, namely the procedural framework and the institutions sued as defendants at each."

In doing so, the court complied with the provisions of art. 248 alin. (1) of Code of Civil Procedure which established its obligation to rule first on procedural or substantive objections which rendered unnecessary, in whole or in part, the administration of evidence or the substantive investigation of the case.

Also, the Court of Appeal took into account the provisions of alin. (5) of the previous article, which expressly stipulates that the exceptions are resolved by the court by a conclusion of a hearing which, in case of rejection of the exception, has an interlocutory character, therefore it cannot be revisited during the trial, it can be attacked only with the merits of the case unless otherwise provided by law.

In addition, as stated above, the appellant company has established the procedural framework, in the sense that it understands to bring the action in contradiction with: - National Agency for Fiscal Administration - General Regional Directorate of Public Finances Galați - Administration of Public Finances, Buzău County defendant as the issuing body of the Taxation Decision and the Decision to resolve the contestation no. 5676/08.12.2016 and,

- The General Directorate for the Administration of Large Taxpayers, the defendant as the administrative body of the company, as well as the issuer of the Decision for solving the administrative contestation no. 60/26.05.2017.

The court of judicial control finds that the appellant, although invoking the provisions of art. 488 alin. (1) para. 8 of Code of Civil Procedure did not formulate criticisms of illegality that could have been subsumed to this reason for cassation.

The solution of the High Court of Cassation and Justice of Romania and the legal basis

Reassessing all the evidence administered in the case and based on all the considerations set out in the previous point, pursuant to art. 20 and art. 28 of the Law on administrative litigation no. 554/2004, republished, with subsequent amendments and completions, reported to art. 496 of Code of Civil Procedure, High Court:

- finds null the appeal declared by the Regional General Directorate of Public Finances Galați, through the Administration of Public Finances, County Buzău against the sentence no. 131 of June 29, 2018, pronounced by the Court of Appeal Ploieşti, civil section II, of administrative and fiscal contentious; 
Dumiter, F.C., Jimon, Ș.A., (2021)

Practical Issues Regarding International Underppinnings of Tax Legislation Under the Auspices of Law No. 296/2020

- dismisses the appeals brought by A. South Central Europe S.A. and the General Directorate for the Administration of Large Taxpayers against the same sentence, as unfounded;

- admits the appeal filed by A. South Central Europe S.A. against the sentence no. 177 of October 17, 2018, pronounced by the Court of Appeal Ploieşti, civil section II, of administrative and fiscal contentious;

- cancel the judgment under appeal and, retrial:

- rejects the objection of inadmissibility of the application, invoked by the General Directorate of Administration of Large Taxpayers;

0 admits the request made by A. South Central Europe S.A.;

- orders the completion of the operative part of sentence no. 131 of June 29, 2018, pronounced by the Court of Appeal Ploieşti, civil section II, of administrative and fiscal contentious, in the sense of obliging the defendants to set minus the amounts representing profit tax declared by the company, in the amount of 1,453,803.04 lei;

- order the appellants-defendants to pay the court costs of 3,000 lei to the appellant-plaintiff A. South Central Europe S.A.

\section{Conclusions and final discussions}

One of the biggest challenges for financial and tax law legislation is the digitization of savings. As a result of the global precautions generated by health issues, national and international economic businesses have undergone significant changes and transformations in the last year. Therefore, the digitization, use of cryptocurrencies, remote working, or technological arrangements of certain types of international business are real contemporary challenges.

The second challenge is the complex fiscal problems that manifest themselves at the level of the national, European, and international fiscal space. The problems of the budget deficit and the increasing level of public debt registered by different states of the world will be felt by the room to maneuver framework generated by the measures of the national fiscal policy in response to the current medical problems. Therefore, the amount and level of taxes, fees, and contributions will increase significantly in the coming years, on the one hand, due to the excessive budget deficit and indebtedness of the states, and on the other hand due to aggressive fiscal planning practiced by different types of companies operating at regional, European and international level.

Consolidation of the national legislative framework through the provisions of Law no. 296/2020 for the amendment and completion of Law no. 227/2015 on the Tax Code is a step forward taken by the Romanian tax authorities to strengthen the national fiscal framework but also to harmonize with various European provisions 
Dumiter, F.C., Jimon, Ș.A., (2021)

Practical Issues Regarding International Underppinnings of Tax Legislation Under the Auspices of Law No. $296 / 2020$

on income and capital taxes. Also, the provisions of Law no. 293/2020 for the amendment and completion of Law no. 227/2015 on the Tax Code established in the field of education contribute to the consolidation of the technical framework.

Analyzing the provisions of Law no. 295/2020 for the amendment of Law no. 207/2015 on the Tax Procedure Code, as well as some fiscal-budgetary measures we can observe an improvement of the administrative and technical framework of the Romanian tax authorities, both at the level of the central apparatus and at the level of the territorial administrative operative units, in terms of concerns the tax procedure.

The case presented in the section on jurisprudential issues at a national level, given issues of tax law with elements of extraneousness is a quid pro quo and faithfully reflects causa proxima for solving in court some problems of fiscal law with elements of foreignness. The solution pronounced by the court regarding the management and research services on the intra-community market in Poland, Hungary, Czech Republic concerns its acceptance of the establishment of the profit tax declared by company A. South Central Europe S.A.

The conclusion that can be deduced from this paper highlights the fact that at a national level it was improved, the national fiscal framework and the regulation of some aspects of international taxation through Law no. 293/2020, Law no. 295/2020, and Law no. 296/2020. From a jurisprudential point of view, the solution pronounced by the court highlights an increasing degree of application of the provisions of European tax law on national tax law in the trial of cases with foreign elements.

\section{Acknowledgments}

The author thanks the anonymous reviewers and editor for their valuable contribution.

\section{Funding}

This research received no specific grant from any funding agency in the public, commercial, or not - for - profit sectors.

\section{Author Contributions}

The authors contributed equally to this article.

\section{Disclosure Statement}

The authors have not any competing financial, professional, or personal interests from other parties. 
Dumiter, F.C., Jimon, Ș.A., (2021)

Practical Issues Regarding International Underppinnings of Tax Legislation Under the Auspices of Law No. 296/2020

\section{References}

1. Dumiter, F.C., (2020). Evitarea dublei impuneri internaționale a profiturilor întreprinderilor, Editura Universul Juridic, București.

2. Dumiter, F.C., Jimon, Ș.A., (2020). Theoretical and Practical Assessments of Transfer Prices. Legal Evidence from Romanian Case Law, Journal of Legal Studies, Vol. 26, No. 40, pp. $1-18$.

3. Dumiter, F.C., Jimon, S.A., Bene, G.F., (2019). Avoiding Double Taxation through the Assessment of International Tax Treaties. Case ESP's versus ANAF Brașov, Journal of Legal Studies, Vol. 23, No. 37, pp. $1-15$.

4. Dumiter, F.C., Jimon, Ș.A., (2018). Taxation of Non - Resident Entities in Romania. Case Rmms versus ANAF Brașov, Journal of Legal Studies, Vol. 21, No. 35, pp. 1 - 15.

5. Dumiter, F.C., Jimon, Ș.A., Boiță, M., (2017). Double Taxation Conventions in Romania: Dsss Râş̧nov vs. ANAF Braşov, Journal of Legal Studies, Vol. 20, No. 34, pp. 1 - 17.

6. De Groot, I., (2015). Exemption Method in the EU Parent-Subsidiary Directive Amended in Respect of Hybrid Instruments: What about the Credit Method?, EC-Tax Review, 2015-3, pp. $158-165$.

7. Khan Niazi, S.U., Krever, R., (2015). Is Integration of Income Taxation Possible in the EU, Australian Tax Forum, 30, pp. $455-470$.

8. Smit, D.S., (2016). International Juridical Double Non-taxation and State Aid, EC-Tax Review, 2016-2, pp. $109-112$.

9. Van der Vijver, A., (2015). International Double (Non-)taxation: Comparative Guidance from European Legal Principles, EC-Tax Review, 2015-5, pp. 240 - 257.

10.*** Law no. $296 / 2020$ on the modification and completion of Law no. 227/2015 regarding the Fiscal Code.

11. *** Law no. 295/2020 on the on the modification and completion of Law no. 207/2015 regarding the Fiscal Procedure Code.

12.*** Law no. 293/2020 on the modification and completion of Law no. 227/2015 regarding the Fiscal Code.

13. *** Law no. 207/2015 on the Fiscal Procedure Code, with subsequent amendments and completions.

14. *** Law no. $227 / 2015$ on the Fiscal Code, with subsequent amendments and completions, including its Implementing Rules.

15.** Law no. 241/2005 for preventing and combating tax evasion, with subsequent amendments and completions.

16. *** Law no. 571/2003 on the Fiscal Code, with subsequent amendments and completions, including its Implementing Rules.

17.*** O.G. no. 92/2003 on the Fiscal Procedure Code, republished, with subsequent amendments and completions, including its Implementing Rules.

18. *** Order no. 222/2008 of February 8, 2008, regarding the content of the transfer prices file. 